OPEN ACCESS

Edited by:

Oleg Brandler,

Russian Academy of Sciences, Russia

Reviewed by:

Lucas Wauters,

University of Insubria, Italy

Maria Vittoria Mazzamuto,

University of Arizona, United States

*Correspondence:

Michael A. Steele

michael.steele@wilkes.edu

Specialty section:

This article was submitted to Behavioral and Evolutionary Ecology,

a section of the journal

Frontiers in Ecology and Evolution

Received: 09 April 2020

Accepted: 14 July 2020

Published: 04 August 2020

Citation:

Steele MA and Yi X (2020)

Squirrel-Seed Interactions:

The Evolutionary Strategies and Impact of Squirrels as Both Seed

Predators and Seed Dispersers.

Front. Ecol. Evol. 8:259.

doi: 10.3389/fevo.2020.00259

\section{Squirrel-Seed Interactions: The Evolutionary Strategies and Impact of Squirrels as Both Seed Predators and Seed Dispersers}

\author{
Michael A. Steele ${ }^{1 *}$ and Xianfeng $\mathrm{Yi}^{2}$ \\ ${ }^{1}$ Department of Biology, Wilkes University, Wilkes-Barre, PA, United States, ${ }^{2}$ College of Life Sciences, Biology, Qufu Normal \\ University, Qufu, China
}

For many squirrel species, their intense - arguably coevolutionary - interactions with seed and nut producing trees have significantly shaped their biology and diversity. Here we provide an overview of this relationship in a range of forest types worldwide. We first review the evidence for how forest composition (conifer, hardwood, mixed hardwood and overall diversity of tree species) influences interactions between squirrels and seed trees and, ultimately, the role of squirrels as either seed predators or seed dispersers. We review, for example, the intense selective pressure squirrels exert on conifer trees as seed predators and the diversity of morphological traits and behavioral strategies that allow them to efficiently exploit this critical resource. In contrast, we show how the squirrel's role shifts to one of seed disperser in hardwood forests and how the specifics of this interaction varies further with forest structure, forest composition and climatic conditions. We then review the growing evidence for the tight ecological and evolutionary dance between the squirrels and the oaks that has shaped the biology of both across the globe. We show how a suite of seed (acorn) characteristics (e.g., chemical gradients, germination schedules, seedling morphology and tolerance-resistance strategies) are all intimately tied to the scatter-hoarding decisions of several squirrel species. And, based on studies in oak forests in Central America, Mexico, North America, and Eurasia, we also highlight the behavioral strategy of embryo excision now reported for six species across at least four genera of squirrels. This behavior, glaringly absent in other scatterhoarding rodents worldwide, is now known be an innate trait in at least two species, one in Asia and another in North America. We review extensive recent research on one species of squirrel, the Siberian chipmunk (Tamias sibiricus), which exhibits a suite of behavioral strategies unique to that of other squirrels that independently contributes to seed dispersal and establishment. Finally, we outline numerous remaining questions concerning plants and other taxa of squirrels still open to investigation.

Keywords: sciuridae, seed predation, seed dispersal, scatterhoarding, coevolution, seed chemistry 


\section{INTRODUCTION}

Among the squirrels, the intensive use of tree seeds has clearly shaped both the biology of trees and their diaspores, which in turn have significantly influenced evolution of the squirrels' behavior, ecology and even some aspects of their morphology. In most, but not all cases, the evidence for tight coevolutionary interactions are not evident, yet the effects and outcomes of the interactions between squirrels and some tree species are nevertheless quite compelling. Steele et al. (2007) and Steele (2008) first reviewed interactions between tree squirrels and trees emphasizing numerous such interactions. Since this earlier research, a significant number of additional studies have further clarified our understanding of these relationships.

Our goal here is to highlight these recent findings and to further focus our understanding of the ecological and evolutionary interaction between squirrels and trees. We are especially interested in distinguishing direct ecological and evolutionary interactions between squirrels and seeds as well as those in which squirrels are more likely a member of a broader array of seed consumers that exhibit a diffuse suite of evolutionary interactions with seed trees and their seeds. We also review recent intensive studies of the Siberian chipmunk (Tamias sibiricus) a resident of conifer, mixed, and hardwood forests across northern Asia, which suggest a relatively tight evolutionary relationship with the oaks, somewhat distinct from that of other squirrel species.

\section{SQUIRRELS AND CONIFER FORESTS}

Tree squirrels are significant seed predators in conifer and mixed forests throughout both temperate and boreal biomes (Steele and Koprowski, 2001; Steele, 2008; Steele et al., 2008; Steele, in press) but under some limited conditions can act as agents of dispersal (Wauters and Casale, 1996; Zong et al., 2010, 2014). In these forests, squirrels consume large quantities of seeds, often approaching entire seed crops, usually in a highly efficient manner which places strong selective pressure on conifers (Smith, 1970, 1998; Elliot, 1974, 1988; Steele and Weigl, 1992; Benkman, 1995, 1999; Benkman et al., 2001; Talluto and Benkman, 2013). But, as several studies have shown, the conifers appear to also exhibit characteristics in direct or indirect response to squirrels. And, in other cases, there is evidence that behavioral and even morphological traits of squirrels follow from conifer and cone traits (see Smith, 1970, 1998).

Seed predation of conifers by squirrels usually results from (1) removal of large quantities of cones just prior to cone opening for the purposes of larder-hoarding for upcoming periods of food scarcity [e.g., Tamiasciurus hudsonicus and T. douglasii in boreal forests of North America (Smith, 1965, 1970, 1981; Steele, 1998, 1999; Boutin et al., 2000, 2006; Siepielski and Benkman, 2007, 2008a,b, 2010)], or (2) consumption of immature, green cones during the ripening of seeds long before cone opening. Examples of the latter include predation of longleaf pine (Pinus palustris) cones by the southeastern fox squirrel, S. niger (Steele, 1988, in press; Steele and Weigl, 1992; Steele and Koprowski, 2001), predation of cones of Ponderosa pine (Pinus ponderosa) by Abert's squirrel (S. aberti), and similar harvesting of immature cones by Eurasian red squirrels (Sciurus vulgaris) in stands of Scots (P. sylvestris) and Corsican pines (P. nigra) in Belgium, and of Norway spruce (Picea abies) and Arolla pine (P. cembra) in mixed conifer forests of the Italian Alps (Wauters and Dhondt, 1987; Molinari et al., 2006; Zong et al., 2010; Di Pierro et al., 2011). As reviewed by Steele (2008) another key manner in which squirrels can influence cone production and seed dispersal in conifers is by the indirect effects of bark stripping not reviewed here.

Direct evolutionary interactions between Tamiasciurus and conifers has been argued independently by both Smith (1970, 1998) and Benkman and colleagues (e.g., Mezquida and Benkman, 2005, 2014), with both suggesting strong evidence for the direct selection between conifers and cones (Steele, in press). Smith (1998) argues that east of the Cascade Range in western North America, the dry climate, due to the rainshadow, results in frequent forest fires. These conditions led to cones of Ponderosa pine that have a hard cone surface, strong, close attachment to the branch, asymmetrical shape at the base and fewer seeds per cone - all characteristics that appear to challenge seed predation by the red squirrel found on the eastern slope of the Cascades. There the American red squirrel exhibits larger body mass, stronger jaw muscles and a more robust lower jaw, necessary for harvesting and opening these serotinous cones. West of the Cascades, where the closely related Douglas squirrel ( $T$. douglasii) is found, there is a wet maritime climate and no forest fires. Cones are non-serotinous and exhibit a soft surface, weak point of attachment to the stem and significantly more seeds per cone. The Douglas squirrel exhibits a smaller body size, weaker jaw muscles and a weaker lower jaw, all of which Smith (1998) suggest follows from the cone's characteristics.

Smith has also argued that across conifer species selection by Tamiasciurus spp. is likely to have differing selective pressures depending on cone and seed size $(1970 ; 1998)$. Smith suggests that strong selection by Tamiasciurus on small cones is likely to result in cones with smaller and fewer seeds per cone, characteristics that contribute to high feeding costs for squirrels. In contrast, conifers species that produce larger seeds are likely to evolve cones that shed their seeds earlier to reduce predation by larderhoarding squirrels.

Research by Craig Benkman and colleagues (e.g., Benkman, 1995; Parchman and Benkman, 2008; Siepielski and Benkman, 2008a,b) paints a similar but equally compelling picture about the evolutionary interactions between Tamiasciurus spp. and at least six conifer species in western North America. One such example is limber pine ( $P$. flexilis), which the squirrels regularly feed on when still immature and attached to the tree (Siepielski and Benkman, 2008a). By comparing sites within the range of limber pine where red squirrels are present today (Rock Mountains) and sites where these squirrels have been absent for more than 10,000 years (Great Basin), the authors found significantly different cone characteristics, with trees investing only half as much energy in seeds per cone where squirrels were present. Where red squirrels were present, cones were found to 
have fewer seeds per cone, smaller seeds, larger cones, more resin per cones, and greater seed-coat thickness, all traits that likely defend against seed predation.

Selection of conifer seed and cone traits by these squirrels also significantly impedes avian dispersal by these pines. Conifers that depend on avian dispersal (by jays and nutcrackers [family Corvidae]) generally exhibit specific seed and cone characteristics (large seed size usually $>90 \mathrm{mg}$, a greater seed-wing ratio, longer periods of seed retention, and specific cone orientation), that favor dispersal by these corvids (Lanner, 1999; Siepielski and Benkman, 2007). However, where pine squirrels are found, resulting seed and cone characteristics generally prevent dispersal by corvids (Siepielski and Benkman, 2007, 2010; Parchman et al., 2011). Where pine squirrels are found in both limber and whitebark pine ( $P$. albicaulis) forests, for example, lower seed densities per cone prevent dispersal by Clark's nutcracker (Nucifraga columbiana) which in turn results in lower tree recruitment and as much as 50\% lower stand densities (Siepielski and Benkman, 2008b).

Benkman and associates have also demonstrated how squirrels influence the close evolutionary relationship between the crossbill (Loxia curvirostra) and conifers. Crossbills appears to have coevolved with lodgepole pine in western North America (Benkman, 1999, 2003; Benkman et al., 2001, 2013), black spruce (Picea mariana) in Newfoundland (Parchman and Benkman, 2002) and in stands of the Allepo pine (P. halepensis) in forests of the Iberian Peninsula (Mezquida and Benkman, 2005). However, this close ecological and evolutionary relationship which significantly benefits seed dispersal is disrupted by pine squirrels in North America and Eurasian red squirrels (S. vulgaris) in the latter region. In the Italian Alps, the Eurasian red squirrel is an intensive seed predator of the Arolla pine during periods of low and moderate seed production but potentially shifts to a conditional mutualist during high seed years, possibly as a result of heavy mast production (Zong et al., 2010). The Arolla pine, which produces large, wingless seeds depends on nutcrackers and Eurasian red squirrels for dispersal. The squirrels are highly dependent on both seeds, directly eaten from the green immature cones and those scatterhoarded for use through the winter and the following spring. Further examination of caching behavior in different habitat types (Norway spruce vs. Arolla pine), show that seed densities per cache were lower and patterns of cache recovery were higher in spruce-dominated forests than in the Arolla pine forests (Zong et al., 2014). Also shown in Alpine forests of Europe, the Eurasian red squirrel avoids seeds of silver fir (Abies alba) over those of Norway spruce, on which they readily consume, most likely as a result of high levels of terpenes (i.e., limonene) in the scales and seeds of the former species (Rubino et al., 2012).

Yet another set of squirrel traits that appear to follow directly from their dependence on conifers for food are both their social system and key aspects of their reproductive strategies. In boreal forests of North America, the social structure of the red squirrel has been attributed to their dependence on conifer seeds, their behavior of larder-hoarding and the need to defend the larders (Smith, 1998). Other reproductive traits that likely follow for this intense dependence on cones is the bequeathal of territories from mothers to young (Larsen and Boutin, 1994), anticipatory parental care by larder-hoarding prior to conception and the ability to anticipate cone masting and increase reproduction well in advance of cone production (Boutin et al., 2006). Subtle differences in social structure, reproductive strategies and home range between Mount Graham red squirrels (T. fremonti grahamensis) in Arizona, United States, and Eurasian red squirrels in the Alps of Italy, both of which occur in conifer forests, appear to be tied closely to availability of cone resources (Mazzamuto et al., 2020).

\section{THE SQUIRRELS IN DECIDUOUS FORESTS}

In deciduous forests, the tree squirrels shift from almost exclusive seed predators to important agents of seed dispersal (Steele et al., 2005; Steele, 2008). This interaction, however, is always accompanied by both negative impact of both seed predation and their contributions to dispersal. It is also complicated by the greater number of seed types, as the diversity of seed trees increases significantly in most hardwood forests, as do the numerous characteristics of hardwood diaspores (Sundaram et al., 2015; Sundaram, 2016). Their positive impact on seeds and nuts follows from their behavior of moving these diaspores from their source trees, storing them in microsites that are often optimal for both germination and storage (e.g., Yi et al., 2013b). This behavior of directed dispersal in which a seed disperser moves seeds to sites also ideal for establishment, in the case of many tree squirrels (Sciurus spp.), occurs because cache microsites optimal for cache storage eventually facilitate seedling establishment if the seed remains in the cache.

\section{Gray Squirrel Responses to the Oaks}

Early studies focused on the food preferences of eastern gray squirrels for the many species of oaks (Quercus spp.) and the primary differences in acorns of red oak (RO, section Lobatae) and those of white oak (WO, section Quercus). Acorns of ROs exhibit higher levels of both lipid ( 20\%) and tannin (5-15\%) than those of the WO (lipid $\sim 10 \%$ and tannin $<2 \%$ ). In addition, RO species exhibit a delayed germination requiring a period of cold stratification before germination is possible. WO species, in contrast, germinate immediately upon seed fall pending water availability. Smallwood and Peters (1986), first demonstrated that these differences in seed chemistry resulted in a food preference for WO acorns with lower tannin, regardless of energy level, early in the autumn. Preferences then shifted to acorns high in energy, regardless of tannin levels later in the winter when energy requirements peaked.

Gray squirrels are highly sensitive to germination schedules, selectively dispersing and caching red oaks over those of WOs due to their differences in perishability that follow directly from these germination patterns (Hadj-Chikh et al., 1996). This sensitivity of gray squirrels to seed perishability extends to acorns infested with weevils (Curculio spp.) and other insect larvae, even when there is no external evidence of infestation, suggesting a particularly keen 
ability to detect acorn suitability for storage (Steele et al., 1996). Several studies (Steele et al., 2001a; Sundaram, 2016; Sundaram et al., 2020) now collectively show that gray squirrels rely on chemical cues from the shell or cotyledon to determine if acorns are no longer dormant. These cues, however, are masked by waxes during dormancy and are only detectable when the waxes degrade during the acorn's emergence from dormancy. Although acorns that are no longer dormant are still suitable for consumption, they are far less likely to be cached by squirrels.

When WOs are cached in early autumn, however, gray squirrels will consistently excise the embryo with a few scrapes of the incisors, removing the embryo and thereby killing the acorn (Fox, 1982), allowing the acorn to remain intact in the cache for up to 6 months (Steele et al., 2001b). Experiments with naive squirrels demonstrate that selective caching of RO acorns over those of WO and the behavior of embryo excision are both innate strategies among eastern gray squirrels (Steele et al., 2006), although the latter is hypothesized to be perfected by trial and error.

The field experiments by Hadj-Chikh et al. (1996), in NE Pennsylvania, showed that squirrels based caching decisions on acorn perishability over handling time (acorn size), an important determinant of caching decisions of gray squirrels in some conditions. Comparable experiments to that of HadjChikh et al. (1996) in central Mexico, on caching decision of the Mexican gray squirrel ( $S$. aureogaster), a closely related congener of the eastern gray squirrel, however, revealed markedly different results. In these temperate, but milder environments of Mexico, the Mexican gray squirrels selectively cached the larger acorns regardless of germination schedules and corresponding perishability. And, across all trials, there was a significant correlation between acorn size (handling time) and caching frequency (Steele, in press). However, most interestingly, when caching acorns of WO species, many of which are larger than those of RO species in Mexico, S. aureogaster consistently excised the embryo of these acorns. Thus, this squirrel is clearly aware of the perishability but likely caching larger acorns for the greater reward. Milder climate in central Mexico may mean this species scatter-hoards acorns for shorter periods and thus focuses on short term rewards rather than long-term storage.

Dormancy and nut size influence not only caching decisions but also the distance seeds are dispersed. For many tree species, dispersal away from the parent tree significantly reduces densitydependent mortality of seed and seedlings by seed predators and pathogens, which is highest near maternal sources (Janzen, 1970; Connell, 1971). Several studies have indicated that RO species are consistently dispersed farther and cached more than WO species (Steele et al., 2001b, 2007, 2011, 2014; Moore et al., 2007; Lichti et al., 2014; Steele, in press). And of course when WOs were dispersed embryos of the acorns were often removed, killing the fruit.

Acorn size, which varies tremendously within and across oak species and influences both dispersal and caching decisions (Steele et al., 2011, 2014). When other acorn traits are controlled for, larger acorns are cached more frequently and dispersed farther from the source (Steele et al., 2007, 2011). In addition, gray squirrels respond to these larger rewards (larger acorns) by dispersing acorns into open areas, some distance from canopy cover (Steele et al., 2011) where, even in the face of a high density of conspecifics, these more preferred acorns are far less susceptible to pilferage (Steele et al., 2014). Based on estimates of predation risks (Steele et al., 2015), we concluded that these sites are relatively immune to pilferage because they are placed where conspecifics are less likely to pilfer caches. Further, this series of studies open up a new line of investigation that suggests that scatter-hoarding squirrels that risk predation for cache sites with lower rates of pilferage may contribute significantly to seed dispersal when they are actually preyed upon when caching (Lichti et al., 2017; Lichti et al., in review).

Taken together, many of these studies suggest that gray squirrels, when faced with multiple choices among different oaks and even other hardwoods, are regularly making a diversity of decisions when scatter-hoarding. Lichti et al. (2014), for example, demonstrated that when presented with paired options of red oak (Q. rubra, RO), white oak (Q. alba, WO) and American chestnut, (Castanea dentata, AC), gray squirrels selectively dispersed RO over WO, RO over AC, but also AC over WO.

\section{The Close Evolutionary Relationship Between Squirrels and Oaks Based on Germination Schedules and Cache Perishability}

Embryo removal or embryo excision by tree squirrels to arrest germination in early germinating acorns (e.g., white oak species [section Quercus]) was first documented by Fox (1982) in eastern gray squirrels and is now known to occur in other species of Sciurus and at least three other genera of Sciuridae that frequently depend on acorns for food storage. To perform this behavior, squirrels simply flip the acorn and with a few quick scrapes of the incisors remove the embryo (Fox, 1982), thereby arresting germination and allowing the otherwise perishable acorn to remain intact during the food storing period (Steele et al., 2001b). Since previous reviews on this interaction (e.g., Steele et al., 2005; Steele, 2008), studies across the globe now show that this behavior occurs under a variety of circumstances, for at least six species of squirrels. Moreover at least two of these species exhibit a definitive innate tendency to perform the behavior (Steele et al., 2006; Xiao and Zhang, 2012).

Experiments on free-ranging gray squirrels Hadj-Chikh et al. (1996) clearly documented that this species is highly sensitive to acorn perishability when making caching decisions, selectively dispersing and caching dormant RO acorns (section Lobatae) over those WO (section Quercus) regardless of acorn size (handling time). And, when even limited numbers of white oak acorns were cached, the embryos of these acorns are removed.

In an extensive series of 18 experimental trials, similar to the six trials conducted by Hadj-Chikh et al. (1996), in which free-ranging Mexican gray squirrels ( $S$. aureogaster) were presented with pairs of six species of native RO acorns and five species of WO acorns, Steele (in press) reports unexpected responses by this species. Squirrels consistently dispersed acorns short distances and stored larger acorns with greater handling time, regardless of oak type (section) and germination schedule. 
Because many of these WO species are larger than those of RO, early germinating WOs were consistently cached more frequently than those of RO. Across these 11 oaks species, Steele (in press) reports a significant correlation between acorn mass and caching frequency. Steele (in press) suggests that this nearly opposite response to that of eastern gray squirrels, likely follows from the milder climate and the shorter period over which acorns are likely stored. Opposite of that reported by Hadj-Chikh et al. (1996), this study suggests that seed size was a more immediate determinant of caching decisions. However, when these WO acorns were cached, squirrels consistently excised embryos, thus indicating a sensitivity and ability to respond to acorn dormancy (Steele et al., 2001b; Steele, in press). These observations suggest that, although immediate priorities for caching shifted in this environment, the squirrels were still secondarily responding to early germination with embryo excision.

Several recent studies in Asia indicate that at least three additional squirrel species including the Pallas' squirrel (Callosciurus erythraeus) (Xiao et al., 2009), Pére David's Rock squirrel (Sciurotamias davidianus) (Xiao et al., 2010) and the Asian red-cheeked squirrel (Dremomys rufigenis) (Xiao and Zhang, 2012) all perform embryo excision on early germinating, non-dormant acorns, as well as a few other seed types. Yet the specific circumstances under which this occurs varies with seed types, squirrel species and masting conditions.

Xiao et al. (2009) reported the responses of free-ranging Pallas's squirrel to early germinating acorns of Quercus variabilis $(\mathrm{QV})$ and nuts of Castanea henryi $(\mathrm{CH})$, which exhibit a delayed germination period. In contrast, to most WO species in North America and Mexico, acorns of QV exhibit high tannin levels. When presented with these contrasting traits, Pallas's squirrels selectively cached $\mathrm{QV}$ acorns over nuts of $\mathrm{CH}$, but excised the embryos of the latter at a much higher frequency. Squirrels also performed embryo excision on $\mathrm{QV}$ acorns as they recovered and re-cached these acorns through the hoarding season. Thus, Pallas's squirrels prioritize lower tannin levels over germination schedule when presented with these conflicting demands, but still depend on embryo excision for management of early germinating nuts.

Also reported by Xiao et al. (2010) in Central China, the endemic Pére David's Rock squirrel performs embryo excision on WO species (Quercus aliena var. acutesevata, Q. serrata var. breviptiolata, Q. variabilis) and two other species that produce dormant seeds: the Qinggang oak (Cyclobalanopsis multinervis) and the Chinese chestnut (Castanea mollissima). However, the frequency of embryo removal is much higher in the WOs and was significantly more evident in higher mast years (Xiao et al., 2010). The authors concluded that the interaction between seed germination and seed masting significantly influenced the squirrel's hoarding decisions. Xiao et al. (2013) also explored how acorn size and dormancy both interacted to influence the behavior of dispersal and embryo excision Pére David's Rock squirrel. As predicted, larger acorns were selectively dispersed father but for those that were early germinating species were more likely to have their embryos removed.

Xiao et al. (2010) presented only acorns of two WO species (Quercus aliena var. acutesevata, Q. serrata var. breviptiolata) to Pére David's Rock squirrel, both of which varied in the frequency of early germination during the hoarding period. These authors found that frequency of germination phenotypes accounted for as much as 40.5 and $21.4 \%$ of the dispersal success in these two species, respectively. This suggested that the relative selection of these phenotypes by this squirrel, combined with their behavior of embryo excision, resulted in frequencydependent selection that likely helps maintain variation in the germination phenotypes in these two species. This suggests a strong evolutionary impact of the squirrel on the acorn germination phenotype.

Collectively, the studies reviewed above show how the behavior of embryo excision is an important behavioral strategy that enables several squirrel species across the globe to manipulate acorn scatter-hoards under a range of environmental situations. Further evidence for the adaptive significance of this behavior follows from two isolated studies, one in North America and another in Southwestern China, that demonstrate the innate basis of this behavior in two squirrel species. In the first, Steele et al. (2006) raised Eastern gray squirrels without any previous experience with acorns and then compared their responses to acorns of the northern red oak (Q. rubra) and the white oak (Q. alba) to those of captive wild-caught squirrels. Both naive and wild squirrels selectively cached RO acorns over those of WO. In addition, wild-caught squirrels consistently excised embryos of early germinating WO acorns. However, naive squirrels also attempted embryo excision of white oak acorns but often failed to successfully excise the embryo. Naive squirrels often attempted to excise embryos from the wrong (basal) end of the acorn or failed to insert the incisors deep enough to successfuly remove the acorn, indicating clearly that the behavior was innate but also in need of additional experience to better optimize outcomes (Steele et al., 2006).

Similarly, Xiao and Zhang (2012) presented free-ranging Asian red-cheeked squirrels (D. rufigenis) with acorns of an early germinating WO (Q. variabilis) and two dormant oaks (Cyclobalanopsis stewardiana and C. glaucoides) in an ancient forest where all WOs species had been extirpated hundreds of years earlier. These squirrels excised embryos of WOs when storing them and on occasion removed embryos of the dormant acorns as well. After eliminating the possibility that these squirrels likely emigrated from distant stands of WOs or learned from other squirrels (e.g., Pallas's squirrel), these authors concluded that the behavior was innate in this species as well.

Evidence of the presence of this behavior in six species of squirrels across four genera worldwide, along with evidence for the innate basis of the behavior in two species, one in North American and the other in Southeast Asia, strongly suggests convergence of this trait in squirrels. This is particularly evident when one considers the broad distribution of this behavior across the phylogeny of the Sciuridae (Steele, in press), coupled with evidence that the behavior appears absent in other squirrels that regularly handle acorns in some parts of their range (e.g., Tamiasciurus spp., S. vulgaris, Tamias spp.).

The behavior of embryo excision by squirrels appears to have also been met with an evolutionary response of WOs. One such example appears to have occurred in acorns of Q. mongolica 
which produces embryonic tissue (seed) set deeper in the acorn farther from the apical tip of the fruit (Zhang et al., 2014). Simulation of embryo excision in this species, compared with several other species with embryos closer to apical end of the fruit (Quercus variabilis, Q. acutissima, Q. aliena, Q. aliena var. acutiserrata, Q. serrata. var. brevipetiolata), suggests a clear advantage to this trait. In all other species, except Q. mongolica, artificial embryo excision resulted in a significant drop in germination and seedling performance. Acorns of Q. mongolica were consistently able to sustain attempts at embryo excision and still successfully germinate. Moreover, Zhang et al. (2014) reported that free-ranging squirrels of several species were far less likely to perform embryo excision on Q. mongolica, compared with acorns of these other oaks.

\section{Partial Acorn Consumption and Diffuse Evolutionary Responses to Seed Size and Chemical Gradients in Acorns}

Although a limited number of squirrel species (six, Table 1) worldwide are now reported to perform embryo excision on early germinating acorns, adaptations of these early germinating oaks present a significant challenge to numerous other seed predators that disperse or feed on these acorns, including several rodents, corvids and insect larvae (e.g., Curculio). Among the rodents, for example, Steele (in press) reports that in eastern deciduous forests of North America, the eastern chipmunk (T. striatus), deer mouse (Peromsucus maniculatus), white-footed mouse ( $P$. leucopus) and the southern flying squirrel (Glaucomys volans) all selectively cache ROs over WOs but show no sign of embryo excision. The first two species are also known from field experiments to selectively disperse $\mathrm{RO}$ acorns over those of early germinating WOs. Despite the challenge these species face with early germinating WOs, there is yet another diffuse co-evolutionary relationship that all of these species appear to collectively engage in with the acorns of oak.

Several rodents, including squirrels, as well as blue jays (Caynocitta cristata) and even Curculio larvae, selectively feed on the basal end of these acorns well away from the embryo, consistently abandoning the seed with much of the cotyledon still intact (Steele et al., 1993, 1998; Perea et al., 2011; Yang and Yi, 2012; Steele, in press). Recent findings (Steele, in press) indicate that in addition to tannins-which are highest in the apical end of the fruit (Steele et al., 1993), near the embryolipids, $\mathrm{Na}$ and potentially other nutrients show an opposite gradient, with levels highest in the basal end of the seed (Figure 1, Steele, in press). Moreover, germination and seedling studies indicate that a notable portion of partially eaten acorns can still germinate and establish as seedlings (Steele, in press), despite the intensity of damage (Bartlow et al., 2018). Numerous early germinating oak species can even sustain complete acorn removal once the radicle is established (Yi et al., 2012b, 2013a, $2015,2019 a)$. Together these observations suggest a diffuse co-evolutionary relationship between multiple seed predators, including the squirrels, and the oaks that quite likely results in significant dispersal of oaks under conditions of high seed abundance.

\section{BEHAVIORAL ADAPTATION OF SIBERIAN CHIPMUNKS TO EARLY GERMINATING OAKS}

One species of squirrel that does not perform embryo excision of early germinating acorns appears to have overcome this problem with a suite of other behavioral strategies that allow it to manage the challenge of early germination (Table 2). Although this species is known to larderhoard food for winter hibernation, the relatively solitary species also regularly engages in scatterhoarding and, as a result, contributes significantly to seed dispersal (Wang et al., 2018; Yi et al., 2019b). In China, Siberian chipmunks ( $T$. sibiricus) exhibit the unique behavior of pericarp removal of acorns of Q. mongolica, Q. variabilis, Q. aliena and Q. serrata var. brevipetiolata (Yi et al., 2012a, 2014; Yang et al., 2018). Similar observations in North America have been attributed to eastern chipmunks (T. striatus, Yi, personal

TABLE 1 | Summary of squirrels that perform embryo excision on early germinating white oaks.

\begin{tabular}{|c|c|c|c|c|}
\hline Species & Location & Oak species/section & Comments & Literature cited \\
\hline $\begin{array}{l}\text { Eastern gray squirrel } \\
\text { Sciurus carolinensis }\end{array}$ & $\begin{array}{l}\text { NE, S. U.S., mid-western } \\
\text { United States }\end{array}$ & $\begin{array}{l}\text { Quercus alba, Q. montanaQ. } \\
\text { Macrocarpa }\end{array}$ & 1,2 & $\begin{array}{l}\text { Fox, 1982; Steele et al., } \\
2001 b, 2006\end{array}$ \\
\hline $\begin{array}{l}\text { Western fox squirrel } \\
\text { Sciurus niger }\end{array}$ & mid-western United States & Q. macrocarpa & 2,3 & Steele, in press \\
\hline $\begin{array}{l}\text { Mexican gray squirrel } \\
\text { Sciurus aureogaster }\end{array}$ & Central Mexico, southward & $\begin{array}{l}\text { Q. glaucoides, Q. laeta, Q. obtusata, Q. } \\
\text { microfila Q. rugosa }\end{array}$ & & $\begin{array}{l}\text { Steele et al., } 2001 \mathrm{~b} ; \\
\text { Steele, in press }\end{array}$ \\
\hline $\begin{array}{l}\text { Pallas' squirrel Callosciurus } \\
\text { erythraeus }\end{array}$ & $\begin{array}{l}\text { Southeast Asia, Southern } \\
\text { China }\end{array}$ & Q. vaiabilis, Castanea henryi & 2 & Xiao et al., 2009 \\
\hline $\begin{array}{l}\text { Pére David's Rock } \\
\text { Sciurotamias davidianus }\end{array}$ & $\begin{array}{l}\text { Endemic to East and } \\
\text { Central China }\end{array}$ & $\begin{array}{l}\text { Q. aliena Q. serrata, Q. } \\
\text { variabilisCyclobalanopsis multinervis } \\
\text { Castanea mollissima }\end{array}$ & 2 & Xiao et al., 2010 \\
\hline $\begin{array}{l}\text { Asian red-cheeked squirrel } \\
\text { Dremomys rufgenis }\end{array}$ & Southeast Asia, China & $\begin{array}{l}\text { Q. variabilis, Cyclobalanopsis } \\
\text { stewardiana, and C. glaucoides }\end{array}$ & 1,2 & Xiao and Zhang, 2012 \\
\hline
\end{tabular}




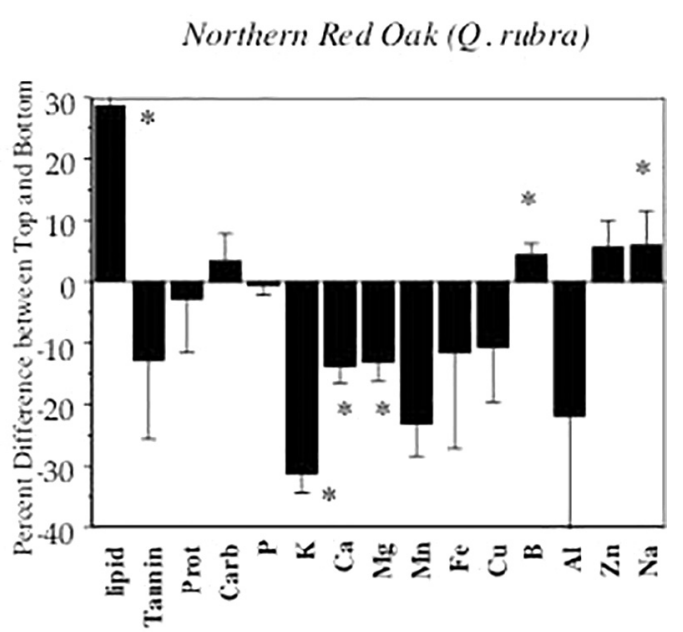

FIGURE 1 | From Steele, Michael A., Oak Seed Dispersal: A Study in Plant Animal Interactions. Figure 6.8b. @ 2021 Johns Hopkins University Press. Modified and reprinted with permission of Johns Hopkins University Press. (A) Distinction of the cotyledon of basal (top) and apical (bottom) halves of northern red oak acorns based on levels of lipid, tannin, carbohydrates, protein and 8 minerals. Results are based on composite samples of top and bottom halves of acorns from each of 20 trees (Steele, in press). Although tannin alone is not significantly higher in apical halves in this analysis (but see Steele et al., 1993), lipid and $\mathrm{Na}$ is higher in the basal half, suggesting that the top is more palatable but also higher in energy. Throughout the literature, it is now known that a suite of acorn seed predators (e.g., squirrels and other rodents, birds, and insect larvae) selectively consume the basal half of acorns and discard the apical halves, along with the embryo (Steele et al., 1993; Perea et al., 2011; Yang and Yi, 2012; Steele, in press), and that these damaged acorns can still germinate and establish (Steele, in press). * indicates significant difference in top and bottom halves at $P<0.05$.

observation). By removing the pericarps of early germinating oaks, Siberian chipmunks are able to selectively discard nearly all insect-infested acorns, and, in turn, maximize the quality of their caches. However, unlike the behavior of embryo excision, pericarp removal does not prevent acorn germination. On the contrary, this behavior has a tendency to enhance seed germination rates of several oak species (Yi et al., 2014; Yang et al., 2018).

Yang et al. (2018) also found that pericarp removal by Siberian chipmunks may prevent cache pilferage by other rodents, especially conspecifics, possibly due to reduced seed odors associated with the pericarps (but see Sundaram et al., 2020). Moreover, field evidence showed that whole acorns cached by wood mice, Apodemus peninsulae, were more likely to be pilfered by Siberian chipmunks than acorns that had pericarps removed. Pilferage rates of whole intact acorns were estimated at $28 \%$ during both periods of both high and low seed abundance (Yi et al., 2019b).

Another behavioral strategy employed by Siberian chipmunks to deal with rapid germination of WOs, is radicle/acorn pruning. Early germinating acorns often develop a substantial radicle early in the autumn. Siberian chipmunks, as well as several other rodents (Yang et al., 2012; Zhang et al., 2017, 2018b), often cut and remove the acorn from the established radicle. This behavior has the potential to slow or stop re-sprouting of radicles and re-germination of acorns. However, it has also been shown that, under many circumstances, radicles over a minimum size are capable of producing new seedlings (Yi et al., 2012b, 2013a).

Yi et al. (2016c) tested the effects of seed odor on the scatter-hoarding and pilfering behavior of Siberian chipmunks. These chipmunks scatter-hoarded more seeds with weaker odors, supporting the hypothesis that olfaction likely plays an important role in the scatter-hoarding process and that chipmunks manage caches based on olfactory cues. This is further supported by experiments by Yi et al. (2016a) in which simulated nitrogen deposition significantly altered seed odor and other seed traits and, in turn, patterns of scatter-hoarding and pilfering by Siberian chipmunks (Yi et al., 2016a).

\section{Acorn tannins and Siberian Chipmunks}

Despite the close interaction between acorns and Siberian chipmunks, tannins in acorns appear to be an important chemical defense for the oaks. Yang and Yi (2012) showed that Siberian chipmunks and other sympatric seed-eating animals tend to selectively consume the basal end of WO (Section Quercus)

TABLE 2 | Summary of a suite of behavioral strategies employed by Siberian chipmunks (Eutamias sibiricus) to manage acorn scatterhoards.

\begin{tabular}{|c|c|c|c|}
\hline Chipmunk characteristic(s) & Oak species & Oak/seed characteristic(s) & Literature cited \\
\hline Pericarp removal prior to scatterhoarding & $\begin{array}{l}\text { Quercus mongolica, Q. } \\
\text { variabilis, Q. aliena and Q. } \\
\text { serrata var. brevipetiolata }\end{array}$ & $\begin{array}{l}\text { Early, rapid germination pericarp } \\
\text { removal may enhance germination and } \\
\text { reduce cache pilferage } 1\end{array}$ & $\begin{array}{l}\text { Yi et al., 2012a, 2014; Yang et al., } \\
2018,2016\end{array}$ \\
\hline $\begin{array}{l}\text { Extensive acorn/radicle pruning which may } \\
\text { slow germination }\end{array}$ & $\begin{array}{l}\text { Q. mongolica, and other } \\
\text { species }\end{array}$ & $\begin{array}{l}\text { Rapid radicle production and ability to } \\
\text { sustain acorn removal }\end{array}$ & $\begin{array}{l}\text { Yang et al., 2012; Zhang et al., } \\
\text { 2014, 2017, 2018a; Yi et al., 2019a }\end{array}$ \\
\hline Partial acorn consumption & Q. mongolica & $\begin{array}{l}\text { Ability to sustain damage and still } \\
\text { germinate and establish }\end{array}$ & $\begin{array}{l}\text { Yang and Yi, 2012; Zhang et al., } \\
\text { 2014; Yi et al., } 2015\end{array}$ \\
\hline $\begin{array}{l}\text { Avoidance of acorns high in tannin; evidence of } \\
\text { tannindegrading bacteria }\end{array}$ & Q. mongolica & $\begin{array}{l}\text { Tannin causes significant weight } \\
\text { loss/mortality }\end{array}$ & Zhang et al., 2018b \\
\hline Extensive pilfering of other species' caches & Q. mongolica & $\mathrm{N} / \mathrm{A}$ & Yi et al., 2019a \\
\hline $\begin{array}{l}\text { Selective predation of weevil (Curculio)-infested } \\
\text { acorns and caching of only sound acorns }\end{array}$ & Q. mongolica & & Yang et al., 2018 \\
\hline
\end{tabular}

1. Also performed by eastern chipmunks in NA (Yi pers. observations) 
acorns, quite likely due to the chemical gradients described above in acorns of other oak species (Steele et al., 1993; Steele, in press). Acorns with this partial damage, given that embryos are avoided, have great potential to established either in the lab or field (Zhang et al., 2014; Yi et al., 2015).

Tannins in acorns also impose significant negative physiological effects on seed-eating animals. Although Siberian chipmunks employ a series of behavioral manipulations on acorns (e.g., pericarp removal and radicle pruning), tannins in acorns are typically not affected by these behaviors. Evidence from both enclosure and field studies showed that Siberian chipmunks tend to avoid artificial seeds with high tannins, but to eat and cache seeds with low tannins (Zhang et al., 2013, but see Xiao et al., 2009 for evidence of selective caching of high tannin acorns by other squirrels). Zhang et al. (2018a) provided further evidence that tannins in acorns results in loss of body mass and population declines of Siberian chipmunks, despite evidence of tannin degrading bacteria in the digestive tract of this squirrel.

\section{Cache Site Selection of Siberian Chipmunks}

The rapid sequestration hypothesis predicts that scatter-hoarding animals quickly store seeds near seed sources to reduce competition when seeds are abundant (e.g., during seed fall). Yi et al. (2019c), however, hypothesized that Siberian chipmunk, as multiple-prey loaders, may rely on an alternative hoarding strategy. By using multiple-compartment enclosures with different distances between the seed source and nest, they found chipmunks consistently placed their caches near nests but away from the seed source. Cache placement near nests may serve as an alternative strategy that not only guarantees a maximum harvest rate at the seed source but also ensures effective cache defense near nests. Moreover, scatter-hoarding seeds near nests may alternatively guarantee a food supply if larder-hoarded seeds are depleted or lost.

Another factor that may potentially influence both cache site selection by rodents is soil water content (SWC). For rodents, higher SWC increases olfactory detection and hence the probability of cache recovery by cache owners, although how it influences potential pilferers in unclear. Yi et al. (2013b) conducted a series of experiments with free-ranging chipmunks in a temperate forest of the Xiaoxing'anling Mountains of northeast China. They showed that Siberian chipmunks selectively cached acorns of Q. mongolica in soil of higher SWC, which may also facilitate later cache recovery. They argue that the selective scatter hoarding in soil of higher SWC represents a form of directed dispersal that may also enhance seedling establishment when seeds are not recovered.

Zhang et al. (2016) provided strong evidence that in large enclosures T. sibiricus preferred to establish their caches adjacent to visual landmarks, which they then later use for cache recovery. In the field Siberian chipmunks were also observed to established more caches in forest gaps rather than under understory (Yang et al., 2016), consistent with the observation of Steele et al. (2015) showing that gray squirrels prefer to establish caches in sites with higher predation risk to avoid cache pilferage.

Yang and Yi (2018) showed the importance of seed distribution patterns in affecting the hoarding behavior of scatterhoarding rodents. Exposed seeds on the ground were more likely to be scatter-hoarded by $T$. sibiricus, while pilfered seeds from artificial caches were more likely to be larder-hoarded than those easily accessible on the ground. Recently, Deng et al. (2020) provided evidence that exclusion of interspecific competition by wood mice reduces seed dispersal and scatter-hoarding by Siberian chipmunks, despite an increase in per capita seed abundance. These studies collectively demonstrate that Siberian chipmunks show flexible behavioral strategies for hoarding in response to food availability.

\section{Spatial Memory, Seed Odor and Scatter-Hoarding by Siberian Chipmunks}

As the predominant scatterhoarder in coniferous and deciduous forests of northeastern China, Siberian chipmunks are expected to store more than several thousand acorns and other nuts annually. Therefore, spatial memory on these cached food items should play an important role in cache recovery by this scatter-hoarding animal. Li et al. (2018) found that T. sibiricus places more attention to, and greater memory of, their caches emitting weak odor for later recovery. This may represent the first study showing that scatterhoarding animals trade off spatial memory on their caches emitting different intensity of seed odors. Wang et al. (2018) provided evidence that improved spatial memory by receiving oral addition of docosahexaenoic acid (DHA) and uridine-5-monophosphate (UMP) significantly increased the relative size of hippocampi of the chipmunks and increased concentration of hippocampal DHA and eicosapentaenoic acid (EPA). Consequently, chipmunks that received DHA and UMP scatterhoarded more seeds than control animals, indicating that scatter hoarding in this mammal is associated with improvement in spatial memory. Recently, Niu et al. (2019) reported that visual and/or auditory cues of conspecifics improve cache-pilfering and hoarding by Siberian chipmunks.

Although Vander Wall (1990; see also Dittel et al., 2017) proposed that scatter-hoarding animals show a cache recovery advantage over naive animals, Yi et al. (2016b) provided contrasting evidence that Siberian chipmunks consistently avoided its own caches while pilfering caches of others, suggesting that they are able to clearly distinguish caches they made from those made by naive conspecifics. The authors predict that spatial memory for cached seeds is necessary for scatter-hoarding animals to not only retrieve the food they buried but also for long-term management of caches (Yi et al., 2016b).

\section{CONCLUSION}

Squirrels exhibit close ecological and evolutionary interactions with the plants on which they feed. These interactions translate into a range of quite negative effects, such as heavy seed 
predation, herbivory and even bark stripping, as well as the critically positive (even mutualistic) effect on seed dispersal (Steele, 2008).

In mixed conifer and boreal forests, squirrels often exert strong selective pressure on trees directly as seed predators, indirectly by interfering with avian seed dispersal and only in limited situations contributing to conifer dispersal. In contrast, in deciduous forests across the globe, squirrels consistently contribute to dispersal and regeneration of numerous hardwood species. Moreover, a range of both hardwood seed traits and behavioral characteristics of squirrels point to a strong mutualism between the two.

Here, we reviewed recent studies that demonstrate a close coevolutionary relationship between some squirrel species and the tree seeds they consume and disperse. These studies indicate both similarities in behavior and other traits across the globe, as well as differences in such traits that vary with climate and forest type. Some of these behavioral traits, such as embryo excision of early germinating WO species, are clearly unique to several squirrel species in North America, Mexico and Asia. Other interactions, in contrast, such as partial acorn consumption in response to chemical gradients in cotyledons, are shared with a community of other seed predators (insect, other rodents and some birds) and thus likely the result of diffuse co-evolutionary interactions. Still

\section{REFERENCES}

Bartlow, A. W., Agosta, S. J., Curtis, R., Yi, X., and Steele, M. A. (2018). Acorn size and tolerance to seed predators: the multiple roles of acorns as food for seed predators, fruit for dispersal and fuel for growth. Int. Zool. 13, 251-266. doi: 10.1111/1749-4877.12287

Benkman, C. W. (1995). The impact of tree squirrels (Tamiasciurus) on limber pine seed dispersal adaptations. Evolution 49, 585-592. doi: 10.1111/j.1558-5646. 1995.tb02295.x

Benkman, C. W. (1999). The selection mosaic and diversifying coevolution between crossbills and lodgepole pine. Am. Nat. 153, S75-S91.

Benkman, C. W. (2003). Divergent selection drives the adaptive radiation of crossbills. Evolution 57, 1176-1181. doi: 10.1111/j.0014-3820.2003.tb00326.x

Benkman, C. W., Holimon, W. C., and Smith, J. W. (2001). The influence of a competitor on the geographic mosaic of coevolution between crossbills and lodgepole pine. Evolution 55, 282-294. doi: 10.1111/j.0014-3820.2001.tb01 293.x

Benkman, C. W., Smith, J. W., Maier, M., Hansen, L., and Talluto, M. V. (2013). Consistency and variation in phenotypic selection exerted by a community of seed predators. Evolution 67, 157-169. doi: 10.1111/j.1558-5646.2012.01736.x

Boutin, S., Larsen, K. W., and Berteaux, D. (2000). Anticipatory parental care: acquiring resources for offspring prior to conception. Proc. R. Soc. B 267, 2081-2085. doi: 10.1098/rspb.2000.1252

Boutin, S., Wauters, L. A., McAdam, A. G., Humphries, M. M., Tosi, G., and Dhondt, A. D. (2006). Anticipatory reproduction and population growth in seed predators. Science 314, 1928-1930. doi: 10.1126/science.1135520

Connell, J. H. (1971). On the role of natural enemies in preventing competitive exclusion in some marine animals and in rain forest trees. Dyn. Popul. 298:312.

Deng, Y., Ju, M., and Yi, X. (2020). Exclusion of interspecific competition reduces scatter-hoarding of Siberian chipmunk Tamias sibiricus: a field study. Integ. Zool. 15, 127-134. doi: 10.1111/1749-4877.12416

Di Pierro, E., Ghisla, A., Wauters, L. A., Molinari, A., Martinoli, A., Gurbell, J., et al. (2011). The effects of seed availability on habitat use by a specialist seed predator. Eur. J. Wild Res. 57, 585-595. doi: 10.1007/s10344-010-0469-7

Dittel, J. W., Perea, R., and Vander Wall, S. B. (2017). Reciprocal pilfering in a seed-caching rodent community: implications for species coexistence. Behav. Ecol. Sociobiol. 71, 1-10. other species of squirrels, such at the Siberian chipmunk, exhibit a suite of behavioral responses to the oaks that appear independent of that of other squirrel species.

\section{AUTHOR CONTRIBUTIONS}

The review is based on a diversity of contributions by MS and XY. MS and XY contributed significantly to several revisions of the manuscript. Both authors contributed to the article and approved the submitted version.

\section{FUNDING}

MS recognizes financial support from The U.S. Fulbright Foundation, United States National Science Foundation (DEB 165511, DEB-02-40963, DEB-05-15756, DEB-10-20889, DBI-9978807, DEB-0642594, and DEB-1556707) the Bullard Fellowship at Harvard University and the Wilkes University Fenner Endowment. XY recognizes funding from the National Natural Science Foundation of China (31760156, 31470113, and 31172101) and the Young Talents Invitation Program of Shandong Provincial Colleges and Universities (2019-6-1).

Elliot, P. F. (1974). Evolutionary responses of plants to seed-eaters: pine squirrel predation on lodgepole pine. Evolution 28, 221-231. doi: 10.1111/j.1558-5646. 1974.tb00741.x

Elliot, P. F. (1988). Foraging behavior of a central-place forager: field tests of theoretical predictions. Am. Nat. 131, 159-174. doi: 10.1086/284784

Fox, J. (1982). Adaptation of gray squirrel behavior to autumn germination by white oak acorns. Evolution 36, 800-809. doi: 10.1111/j.1558-5646.1982. tb05446.x

Hadj-Chikh, L. Z., Steele, M. A., and Smallwood, P. D. (1996). Caching behavior of gray squirrels: test of the perishability and handling-time hypotheses. Anim. Behav. 52, 941-948. doi: 10.1006/anbe.1996.0242

Janzen, D. H. (1970). Herbivores and the number of tree species in tropical forests. Am. Nat. 104, 501-528. doi: 10.1086/282687

Lanner, R. M. (1999). Made for Each Other: A Symbiosis of Birds and Pines. Oxford U.K: Oxford University Press.

Larsen, K. W., and Boutin, S. (1994). Movements, survival and settlement of red squirrel (Tamiasciurus hudsonicus) offspring. Ecology 75, 214-223. doi: $10.2307 / 1939395$

Li, Y., Zhang, D., Zhang, H., Wang, Z., and Yi, X. (2018). Scatter-hoarding animal places more memory on caches with weak odor. Behav. Ecol. Sociobiol. $72,1-8$.

Lichti, N. I., Steele, M. A., and Swihart, R. K. (2017). Seed fate and decision-making processes in scatter-hoarding rodents. Biol. Rev. 92, 474-504. doi: 10.1111/brv. 12240

Lichti, N. I., Steele, M. A., Zhang, H., and Swihart, R. K. (2014). Mast species composition alters seed fate in North American rodent-dispersed hardwoods. Ecology 95, 1746-1758. doi: 10.1890/13-1657.1

Mazzamuto, M. V., Merrick, M. J., Bisi, F., Koprowski, J. L., Wauters, L., and Martinoli, A. (2020). Timing of resource availability drives divergent social systems and home range dynamics in ecologically similar tree squirrels. Front. Ecol. Evol. 8:174. doi: 10.3389/fevo.2020.00174

Mezquida, E., and Benkman, C. W. (2005). The geographic selection mosaic for squirrels, crossbills and Aleppo pine. J. Evol. Biol. 18, 348-357. doi: 10.1111/j. 1420-9101.2004.00846.x

Mezquida, E., and Benkman, C. W. (2014). Causes of variation in biotic interaction strength and phenotypic selection along altitudinal gradient. Evolution 68, 1710-1721. doi: 10.1111/evo.12394 
Molinari, A., Wauters, L. A., Airoldi, G., Cerinotti, F., Martinoli, A., and Tosi, G. (2006). Cone selection by Eurasian red squirrels in mixed conifer forests in the Italian Alps. Acta Oecol. 30, 1-10. doi: 10.1016/j.actao.2005. 11.004

Moore, J. E., McEuen, A. B., Swihart, R. K., Contreras, T. A., and Steele, M. A. (2007). Determinants of seed removal distance by scatter-hoarding rodents in deciduous forests. Ecology 88, 2529-2540. doi: 10.1890/07-0247.1

Niu, H., Chu, W., Yi, X., and Zhang, H. (2019). Visual and auditory cues facilitate cache pilferage of Siberian chipmunks (Tamias sibiricus) under indoor conditions. Integ. Zool. 14, 354-365. doi: 10.1111/1749-4877.12373

Parchman, T. L., and Benkman, C. W. (2002). Diversifying coevolution between crossbills and black spruce on Newfoundland. Evolution 56, 1663-1672. doi: 10.1111/j.0014-3820.2002.tb01478.x

Parchman, T. L., and Benkman, C. W. (2008). The geographic selection mosaic for ponderosa pine and crossbills: a tale of two squirrels. Evolution 62, 348-360. doi: 10.1111/j.1558-5646.2007.00295.x

Parchman, T. L., Benkman, C. W., Jenkins, B., and Buerkle, C. A. (2011). Low levels of population genetic structure in lodgepole pine across a geographic mosaic of coevolution. Am. J. Bot. 98, 669-679. doi: 10.3732/ajb.1000378

Perea, R., San Miguel, A., and Gil, L. (2011). Leftovers in seed dispersal: ecological implications of partial seed consumption for oak regeneration. J. Ecol. 99, 194-201. doi: 10.1111/j.1365-2745.2010.01749.x

Rubino, F. M., Martinoli, A., Pitton, M., Di Fabio, D., Caruso, E., Banfi, S., et al. (2012). Food choice of Eurasian red squirrels and concentrations of antipredatory secondary compounds. Mamm. Biol. 77, 332-338. doi: 10.1016/j. mambio.2012.01.003

Siepielski, A. M., and Benkman, C. W. (2007). Selection by a pre-dispersal seed predator constrains the evolution of avian seed dispersal in pines. Funct. Ecol. 21, 611-618. doi: 10.1111/j.1365-2435.2007.01261.x

Siepielski, A. M., and Benkman, C. W. (2008a). A seed predator drives the evolution of a seed dispersal mutualism. Proc. R. Soc. Lond. B Biol. Sci. 275, 1917-1925. doi: $10.1098 / \mathrm{rspb} .2008 .0451$

Siepielski, A. M., and Benkman, C. W. (2008b). Seed predation and selection exerted by a seed predator influence subalpine tree densities. Ecology 89, 2960-2966. doi: 10.1890/08-0072.1

Siepielski, A. M., and Benkman, C. W. (2010). Conflicting selection from an antagonist and a mutualist enhances phenotypic variation in a plant. Evolution 64, 1120-1128. doi: 10.1111/j.1558-5646.2009.00867.x

Smallwood, P. D., and Peters, W. D. (1986). Grey squirrel food preferences: the effects of tannin and fat concentration. Ecology 67, 168-174. doi: 10.2307/ 1938515

Smith, C. C. (1965). The Coevolution of Plants and Seed Predators. Ph. D. Thesis, University of Texas, Austin, TX.

Smith, C. C. (1970). The coevolution of pine squirrels (Tamiasciurus) and conifers. Ecol. Monog. 40, 349-371. doi: 10.2307/1942287

Smith, C. C. (1981). The indivisible niche of Tamiasciurus: an example of non-partitioning of resources. Ecol. Monog. 51, 343-363. doi: 10.2307/293 7278

Smith, C. C. (1998). "The evolution of reproduction in trees: Its effect on squirrel ecology and behavior," in Ecology and Evolutionary Biology of Tree Squirrels, eds M. A. Steele, J. F. Merritt, and D. A. Zegers (Martinsville, VA: Virginia Museum of Natural History), 204-210.

Steele, M. A. (1988). Patch Use and Foraging Ecology of the Fox Squirrel: Tests of Theoretical Predictions. Doctural Dissertation Wake Forest University, Winston-Salem, NC.

Steele, M. A. (1998). Tamiasciurus hudsonicus. Mamm. Sp. 586, 1-9.

Steele, M. A. (1999). Tamiasciurus douglasii. Mamm. Sp. 630, 1-8.

Steele, M. A. (2008). Evolutionary interactions between tree squirrels and trees: a review and synthesis. Curr. Sci. 95, 271-276.

Steele, M. A. (in press). Oak Seed Dispersal: A Study of Plant-Animal Interactions. Baltimore MD: Johns Hopkins University Press.

Steele, M. A., Bugdal, M., Yuan, A., Bartlow, A., Buzalewski, J., Lichti, N., and Swihart, R. (2011). Cache placement, pilfering, and a recovery advantage in a seed-dispersing rodent: could predation of scatter hoarders contribute to seedling establishment?. Acta Oecol. 37, 554-560. doi: 10.1016/j.actao.2011. 05.002

Steele, M. A., Contreras, T. A., Hadj-Chikh, L. Z., Agosta, S. J., Smallwood, P. D., and Tomlinson, C. N. (2014). Do scatter-hoarders trade off increased predation risks for lower rates of cache pilferage? Behav. Ecol. 25, 206-215. doi: 10.1093/ beheco/art107

Steele, M. A, Carlson, J. E., Smallwood, P. D., McEuen, A. B., Contreras, T. A., and Terzaghi, W. B. (2007). "Linking seed and seed shadows: a case study in the oaks (Quercus)," in Seed Dispersal: Theory and its Application in a Changing World, eds A. J. Dennis, E. W. Schupp, R. J. Green, and D. A. Wescott (CAB International), 231-232.

Steele, M. A., Gavel, K., and Bachman, W. (1998). "Dispersal of half-eaten acorns by gray squirrels: effects of physical and chemical seed characteristics," in Ecology and Evolutionary Biology of Tree Squirrels, eds M. A. Steele, J. F. Merritt, and D. A. Zegers (Martinsville, VA: Virginia Museum of Natural History), 223-231.

Steele, M. A., Hadj-Chikh, L. Z., and Hazeltine, J. (1996). Caching and feeding behavior of graysquirrels: responses to weevil infested acorns. J. Mamm. 77, 304-314. doi: 10.2307/1382802

Steele, M. A., Halkin, S. L., Smallwood, P. D., McKenna, T. J., Mitsopoulos, K., and Beam, M. (2008). Cache protection strategies of a scatter-hoarding rodent: do tree squirrels engage in behavioural deception? Anim. Behav. 75, 705-714. doi: 10.1016/j.anbehav.2007.07.026

Steele, M. A., Knowles, T., Bridle, K., and Simms, E. L. (1993). Tannins and partial consumption of acorns: implications for dispersal of oaks by seed predators. Am. Midl. Nat. 130, 229-238.

Steele, M. A., and Koprowski, J. L. (2001). North American Tree Squirrels. Washington, D.C: Smithsonian Institution Press.

Steele, M. A., Manierre, S., Genna, T., Contreras, T. A., Smallwood, P. D., and Pereira, M. E. (2006). The innate basis of food-hoarding decisions in grey squirrels: evidence for behavioural adaptations to the oaks. Anim. Behav. 71, 155-160. doi: 10.1016/j.anbehav.2005.05.005

Steele, M. A, Rompre, G., Zhang, H., Stratford, J., Suchocki, M., and Marino, S. (2015). Scatterhoarding rodents favor higher predation risks for cache sites: the potential for predators to influence the seed dispersal process. Integ. Zool. 10, 257-266. doi: 10.1111/1749-4877.12134

Steele, M. A., Smallwood, P. D., Spunar, A., and Nelsen, E. (2001a). The proximate basis of the oak dispersal syndrome: detection of seed dormancy by rodents. Am. Zool. 41, 852-864. doi: 10.1093/icb/41.4.852

Steele, M. A., Turner, G., Smallwood, P. D., Wolff, J. O., and Radillo, J. (2001b). Cache management by small mammals: Experimental evidence for the significance of acorn-embryo excision. J. Mamm. 82, 35-42. doi: 10.1093/ jmammal/82.1.35

Steele, M. A., Wauters, L., and Larsen, K. (2005). "Selection, predation, and dispersal of seeds by tree squirrels in temperate and boreal forests: are tree squirrels keystone granivores?," in Seed Fate: Predation, Dispersal and Seedling Establishment, eds P. M. Forget, J. Lambert, P. Hulme, and S. Vander Wall (Wallingford: CAB International), 205-219.

Steele, M. A., and Weigl, P. D. (1992). Energetics and patch use in the fox squirrel: responses to prey density and patch profitability. Amer. Midl. Natur. 128, 156-167.

Sundaram, M. (2016). The Role of Seed Attributes in Eastern Gray Squirrel Foraging. Doctural Dissertation, Purdue University, West Lafayette, IN.

Sundaram, M., Higdon, A. E., Wood, K. V., Bonham, C. C., and Swihart, R. K. (2020). Mechanisms underlying detection of seed dormancy by a scatter-hoarding rodent. Integ. Zool. 15, 89-102. doi: 10.1111/1749-4877. 12417

Sundaram, M., Willoughby, J. R., Lichti, N. I, Steele, M. A., and Swihart, R. K. (2015). Segregating the effects of seed traits and common ancestry of hardwood trees on eastern gray squirrel foraging decisions. PLoS One 10:e130942. doi: 10.1371/journal.pone.0130942

Talluto, M. V., and Benkman, C. W. (2013). Landscape-scale eco-evolutionary dynamics: selection by seed predators and fire determine a major reproductive strategy. Ecology 94, 1307-1316. doi: 10.1890/12-2058.1

Vander Wall, S. B. (1990). Food Hoarding in Animals. Chicago, Il: Chicago University Press.

Wang, M., Zhang, D., Wang, Z., and Yi, X. (2018). Improved spatial memory promotes scatter-hoarding of animals. J. Mamm. 99, 1189-1196. doi: 10.1093/ jmammal/gyy109

Wauters, L. A., and Casale, P. (1996). Long-term scatterhoarding by Eurasian red squirrels (Sciurus vulgaris). J. Zool. 238, 195-207. doi: 10.1111/j.1469-7998. 1996.tb05389.x 
Wauters, L. A., and Dhondt, A. A. (1987). Activity budget and foraging-behaviour of the red squirrel (Sciurus vulgaris, Linnaeus, 1758) in a coniferous habitat. Zeitschrift für Saugetkunde 52, 341-352.

Xiao, Z., Gao, X., Jiang, M., and Zhang, Z. (2009). Behavioral adaptation of Pallas's squirrels to germination schedule and tannins in acorns. Behav. Ecol. 20, 1050-1055. doi: 10.1093/beheco/arp096

Xiao, Z., Gao, X., Steele, M. A., and Zhang, Z. (2010). Frequency-dependent selection by tree squirrels: adaptive escape of nondormant white oaks. Behav. Ecol. 21, 169-175. doi: 10.1093/beheco/arp169

Xiao, Z., Gao, X., and Zhang, Z. (2013). The combined effects of seed perishability and seed size on hoarding decisions by Pére David's rock squirrels. Beh. Ecol. Sociobiol. 67, 1067-1075. doi: 10.1007/s00265-013-1531-8

Xiao, Z., and Zhang, Z. (2012). Behavioral responses to acorn germination by tree squirrels in an old forest where white oaks have long been extirpated. Anim. Behav. 84, 945-951. doi: 10.1016/j.anbehav.2012.01.013

Yang, Y., Wang, Z., Yan, C., Zhang, Y., Zhang, D., and Yi, X. (2018). Selective predation on acorn weevils by seed-caching Siberian chipmunk Tamias sibiricus in a tripartite interaction. Oecology 188, 149-158. doi: 10.1007/s00442-0184161-z

Yang, Y., and Yi, X. (2012). Partial acorn consumption by small rodents: implication for regeneration of white oak, Quercus mongolica. Plant Ecol. 213, 197-205. doi: 10.1007/s11258-011-0016-y

Yang, Y., and Yi, X. (2018). Scatterhoarders move pilfered seeds into their burrows. Behav. Ecol. Sociobiol. 72, 158.

Yang, Y., Yi, X., and Yu, F. (2012). Repeated radicle pruning of Quercus mongolica acorns as a cache management tactic of Siberian chipmunks. Acta Ethol. 15, 9-14. doi: 10.1007/s10211-011-0102-0

Yang, Y., Zhang, M., and Yi, X. (2016). Small rodents trading off forest gaps for scatter-hoarding differs between seed species. For. Ecol. Manag. 379, 226-231. doi: 10.1016/j.foreco.2016.08.005

Yi, X., Bartlow, A. W., Curtis, R., Agosta, S. J., and Steele, M. A. (2019a). Responses of seedling growth and survival to post-germination cotyledon removal: An investigation among seven oak species. J. Ecol. 107, 1817-1827. doi: 10.1111/ 1365-2745.13153

Yi, X., Curtis, R., Bartlow, A. W., Agosta, S. J., and Steele, M. A. (2013a). Ability of chestnut oak to tolerate acorn pruning by rodents. Naturwissenschaften 100 , 81-90. doi: 10.1007/s00114-012-0996-Z

Yi, X., Ju, M., Yang, Y., and Zhang, M. (2019b). Scatter-hoarding and cache pilfering of rodents in response to seed abundance. Ethology 125, 492-499. doi: $10.1111 /$ eth.12874

Yi, X., Li, J., Zhang, M., Zhang, D., and Wang, Z. (2016a). Short-term acute nitrogen deposition alters the interaction between Korean pine seeds and food hoarding rodents. Forest Ecol. Manag. 367, 80-85. doi: 10.1016/j.foreco.2016. 02.025

Yi, X., Liu, G., Steele, M. A., Shen, Z., and Liu, C. (2013b). Directed seed dispersal by a scatter-hoarding rodent: the effects of soil water content. Anim. Behav. 86, 851-857. doi: 10.1016/j.anbehav.2013.07.028

Yi, X., Steele, M. A., Stratford, J. A., Wang, Z., and Yang, Y. (2016b). The use of spatial memory for cache management by a scatter-hoarding rodent. Behav. Ecol. Sociobiol. 70, 1527-1534. doi: 10.1007/s00265-016-2 161-8

Yi, X., Steele, M. A., and Zhang, Z. (2012a). Acorn pericarp removal as a cache management strategy of the Siberian chipmunk, Tamias sibiricus. Ethology 118, 87-94. doi: 10.1111/j.1439-0310.2011.01989.x
Yi, X., Wang, Z., Liu, C., Liu, G., and Zhang, M. (2015). Acorn cotyledons are larger than their seedlings' need: evidence from artificial cutting experiments. Sci. Rep. 5:8112.

Yi, X., Wang, Z., Zhang, H., and Zhang, Z. (2016c). Weak olfaction increases seed scatter-hoarding by Siberian chipmunks: implication in shaping plant-animal interactions. Oikos 125, 1717-1718.

Yi, X., Yang, Y., Curtis, R., Bartlow, A. W., Agosta, S. J., and Steele, M. A. (2012b). Alternative strategies of seed predator escape by early-germinating oaks in Asia and North America. Ecol. Evolution 2, 487-492. doi: 10.1002/ece3.209

Yi, X., Yang, Y., and Zhang, M. (2019c). Cache placement near nests by a multipleprey loader, the Siberian chipmunk. Anim. Behav. 15, 1-8. doi: 10.1016/j. anbehav.2019.06.024

Yi, X., Zhang, M., Bartlow, A. W., and Dong, Z. (2014). Incorporating cache management behavior into seed dispersal: the effect of pericarp removal on acorn germination. PLoS One 9:e92544. doi: 10.1371/journal.pone.0092544

Zhang, D., Li, J., Wang, Z., and Yi, X. (2016). Visual landmark-directed scatterhoarding of Siberian chipmunks Tamias sibiricus. Integr. Zool. 11, 175-181. doi: 10.1111/1749-4877.12171

Zhang, M., Dong, Z., Yi, X., and Bartlow, A. W. (2014). Acorns containing deeper plumule survive better: how white oaks counter embryo excision by rodents. Ecol. Evol. 4, 59-66. doi: 10.1002/ece3.898

Zhang, M., Steele, M. A., and Yi, X. (2013). Reconsidering the effects of tannin on seed dispersal by rodents: evidence from enclosure and field experiments with artificial seeds. Behav. Process. 100, 200-207. doi: 10.1016/j.beproc.2013.09.010

Zhang, Y., Bartlow, A. W., Wang, Z., and Yi, X. (2018a). Effects of tannins on population dynamics of sympatric seed-eating rodents: the potential role of gut tannin-degrading bacteria. Oecology 187, 667-678. doi: 10.1007/s00442-0184151-1

Zhang, Y., Li, W., Sichilima, A. M., Lu, J., and Wang, Z. (2017). Discriminatory pre-hoarding handling and hoarding behaviour towards germinated acorns by Niviventer confucianus. Ethol. Ecol. Evol. 30, 1-11. doi: 10.1080/03949370.2017. 1282542

Zhang, Y., Shi, Y., Sichilima, A. M., Zhu, M., and Lu, J. (2018b). Evidence on the adaptive recruitment of Chinese cork oak (Quercus variabilis $\mathrm{Bl}$.): influence on repeated germination and constraint germination by food-hoarding animals. Forests 7:47. doi: 10.3390/f7020047

Zong, C., Mei, S., Santicchia, F., Wauters, L. A., Preatoni, D. G., and Martinoli, A. (2014). Habitat effects on hoarding plasticity in the Eurasian red squirrel (Sciurus vulgaris). Hystrix 25, 14-17. doi: 10.4404/hystrix-25.1-10160

Zong, C., Wauters, L. A., Van Dongen, S., Mari, V., Romeo, C., Martinoli, A., et al. (2010). Annual variation in predation and dispersal of Arolla pine (Pinus cembra L.) seeds by Eurasian red squirrels and other seed-eaters. Forest Ecol. Manag. 260, 587-594. doi: 10.1016/j.foreco.2010.05.01

Conflict of Interest: The authors declare that the research was conducted in the absence of any commercial or financial relationships that could be construed as a potential conflict of interest.

Copyright (c) 2020 Steele and Yi. This is an open-access article distributed under the terms of the Creative Commons Attribution License (CC BY). The use, distribution or reproduction in other forums is permitted, provided the original author(s) and the copyright owner(s) are credited and that the original publication in this journal is cited, in accordance with accepted academic practice. No use, distribution or reproduction is permitted which does not comply with these terms. 